\title{
My Brother has Down Syndrome but What About Me? Meeting the Needs of Siblings
}

\author{
Ron Malcolm* \\ University of Phoenix, University of Kansas, Kansas City, Kansas, United States
}

Submission: January 25, 2019; Published: January 30, 2019

*Corresponding author: Ron Malcolm, University of Phoenix, University of Kansas, 2532 N 107th Street, Kansas City, Kansas, United States

\section{Plan A Classroom Visit}

Some students with Down Syndrome may be educated in a regular education classroom with their non-disabled peers. Others may be educated in a resource room setting. Parents can work with schools to encourage them to have an Open House for the siblings of the students with Down Syndrome. Students can visit classrooms of their siblings, see their work displayed, meet some of their Down Syndrome friends, look at the materials they utilize throughout their school day or even sit at their desk.

\section{Attend a Special Olympics Event}

Getting your child with Down Syndrome involved in Special Olympics is a great idea. It can assist them with staying physically healthy as well as being able to make lifetime friends. Having the non-disabled siblings attend one of these Special Olympic Events is also a great idea. They can involve themselves in some fun activities and learn from their experience by volunteering. It will allow them to meet some of the friends of their siblings. It will assist with their understanding that all people with Down Syndrome are not the same. Each person with Down Syndrome has their own unique skills and abilities.

\section{Create School Displays}

Almost all schools have bulletin boards. Most teachers would welcome some extra hands with decorating a bulletin board with a new twist or theme. Siblings could develop a bulletin board focused on their own siblings with Down Syndrome and their special accomplishments or talents. Other creative ideas could be for non-disabled siblings to decorate a bulletin board about factual information in regards to Down Syndrome, famous people with Down Syndrome or even different ways that some people with Down Syndrome communicate such as: augmentative communication devices, picture exchange systems or even American Sign Language.

\section{Get to know the Neighbors}

There are many individuals with Down Syndrome that are making significant contributions in the community. Parents can ask school administrators to host panel discussions with community members who have Down Syndrome. Inviting adults with Down Syndrome or high school students with Down Syndrome to discuss their daily challenges, discrimination that they might encounter, their education, careers, and their families. A panel discussion could also include bringing in high school students who have a sibling with Down Syndrome to talk about their experiences growing up with a sibling with Down Syndrome, going to school together with that sibling, how to address bullying at school or in the neighborhood or how their family is impacted in a positive manner by the addition of a sibling with Down Syndrome.

\section{Show Down Syndrome Related Movies}

Siblings can benefit from watching movies that feature individuals with Down Syndrome. While this would have been viewed as uncommon 20 years ago, there is a cascade of individuals with Down Syndrome appearing in movies. Such individuals and movies include: Lauren Potter (Glee), Chris Parisi (Call the MidWife), Megan Bomgaars, Rachel Osterbach, Sean McElwee and John Tucker (Born This Way) are just a few of many that are available. These movies display individuals with Down Syndrome in a positive and meaningful light.

\section{Start a Friendship Club}

Parents can encourage their local school to sponsor a Friendship Club. This could be a Club where non-disabled students befriend a student with Down Syndrome. They could eat lunch with them, study together, play with them during recess, or partner with them in physical education, art or music class. Students with siblings who have Down Syndrome could benefit by working and interacting with other individuals at their school who also have Down Syndrome.

\section{Upgrade the School Library}

Every school library could benefit from having books on their shelves that deal with the topic of Down Syndrome. Parents can speak to the school librarian and encourage them purchase such books. Parents can also become involved with their local PTA to assist with fundraising to purchase these books. These could include such books as: 
i. The Best Worst Brother

ii. My Sister Alicia May

iii. Fasten Your Seatbelts - A Crash Course on Down Syndrome for Brothers and Sisters

iv. Be Good to Eddie Lee

v. My Friend Has Down Syndrome

Students who have siblings with Down Syndrome will enjoy locating books in their school library that have characters that look like their own siblings. They can also share these books with their friends at school so they gain a better understanding of Down Syndrome as well.

\section{Celebrate Down Syndrome Month}

Each October, parents can become involved with their local school system to assist them with celebrating Down Syndrome month. Students with siblings who have Down Syndrome can benefit from observing and interacting with other students at their school while they decorate school bulletin boards to celebrate Down Syndrome month, write poetry about Down Syndrome, deliver information about Down Syndrome daily on the morning school announcements, show school related movies about Down Syndrome, sponsor a poster contest surrounding the theme of Down Syndrome, art work dealing with Down Syndrome or host a variety of community speakers who have

This work is licensed under Creative Commons Attribution 4.0 License DOI: 10.19080/GJIDD.2019.06.555680
Down Syndrome etc. The month of October is an excellent chance to spread awareness, advocacy and inclusion for individuals with Down Syndrome. It is a great opportunity to highlight the abilities and accomplishments of students with Down Syndrome.

\section{Lunch Bunch}

Lunch Bunch can be a fun time for non-disabled siblings to interact with their own siblings during lunch or with another student with Down Syndrome. They can eat in the cafeteria with the student with Down Syndrome or invite them to their classroom to eat lunch with them. This will enhance the social opportunities for everyone involved.

\section{Form Small Discussion Groups}

There are times that children will be more open to discussing their concerns and questions with school personnel rather than their own parents. In order to provide this opportunity, parents could encourage school counselors or social workers to develop small discussion groups. These groups could be comprised of students who have siblings with disabilities, including Down Syndrome. This will give siblings an opportunity to share their feelings and concerns with each other is a safe and open environment. This will also allow these siblings to witness the feelings and concerns of other children who have a sibling with a disability. It will enhance their understanding that many of the feelings and frustrations they encounter are normal.

\section{Your next submission with Juniper Publishers} will reach you the below assets

- Quality Editorial service

- Swift Peer Review

- Reprints availability

- E-prints Service

- Manuscript Podcast for convenient understanding

- Global attainment for your research

- Manuscript accessibility in different formats ( Pdf, E-pub, Full Text, Audio)

- Unceasing customer service

Track the below URL for one-step submission https://juniperpublishers.com/online-submission.php 